\title{
“CHARACTERISTIC LOAD” PRINCIPLE
}

\author{
Alexander S. Gorodetsky ${ }^{1}$, Maria S. Barabash ${ }^{1,2}$, Maryna A. Romashkina ${ }^{1}$, \\ Andrii V. Tomashevsky, \\ 1 "LIRA SAPR" Ltd, Kiev, UKRAINE \\ ${ }^{2}$ National Aviation University, Kiev, UKRAINE
}

\begin{abstract}
The article discusses examples of the application of the principle of "characteristic load" (calculations taking into account engineering non-linearity; the designation of subgrade reaction moduli; the designation of the sizes of shelves for beam grillage). The principle of "characteristic load" on the one hand implements the consideration of various factors that are not available when calculating in a linear formulation, on the other hand, it preserves the traditional calculation technology.
\end{abstract}

Keywords: characteristic load, engineering nonlinearity, moduli of subgrade reaction, beam grillage, ribbed floor

\section{ПРИНЦИП «ОПРЕДЕЛЯЮЩЕЕ НАГРУЖЕНИЕ»}

\author{
А.С. Городецкий ${ }^{1}$ М.С. Барабаш ${ }^{1,2}$, М.А. Ромашкина ${ }^{1}$, \\ А.В. Томашевский 1,2 \\ ${ }^{1}$ ООО «ЛИРА САПР, г. Киев, УКРАИНА \\ ${ }^{2}$ Национальный авиационный университет, г. Киев, УКРАИНА
}

\begin{abstract}
Аннотация: В статье рассматривается примеры применения принципа «определяющее нагружение» (расчеты с учетом инженерной нелинейности; назначении коэффициентов постели; назначении размеров полок для балочного ростверка). Принцип «определяющее нагружение» с одной стороны реализует учет различных факторов, недоступных при расчете в линейной постановке, с другой стороны сохраняет традиционную технологию расчета.
\end{abstract}

Ключевые слова: определяющее нагружение, инженерная нелинейность, коэффициентов постели, балочный ростверк, ребристое перекрытие

Modern software systems allow computer modeling of the life cycle of structures - loading processes, erection processes, dynamic impact processes, various force majeure situations, etc. Figure 1 shows the structural methodological scheme for modeling a building object, taking into account all the processes of changing the stress-strain state (SSS) of structures at each stage.

Assemblage stages correspond to the sequence of construction, each of which "stores" the loading history. The stages are successively replaced by each other, respectively, the constructed structure at each stage has a modified. The last ASk stage corresponds SSS to the erected structure, and its SSS "stores" all the information of the erection sequence associated with changes in the structural scheme, addition and removal of mounting loads, etc.

The ASk stage is the starting stage for calculating operational loads. The SSS at the operational stages is determined by the calculation for various combinations of loads (DCL1 - operational static loads; DCL2 payloads taking into account the pulsating wind component, DCL2 - payloads taking into account seismic effects, etc.). Some operational stages, in turn, are the starting ones for modeling force majeure situations that may arise with some probability $\mathrm{Pj}[1,5-6]$. 


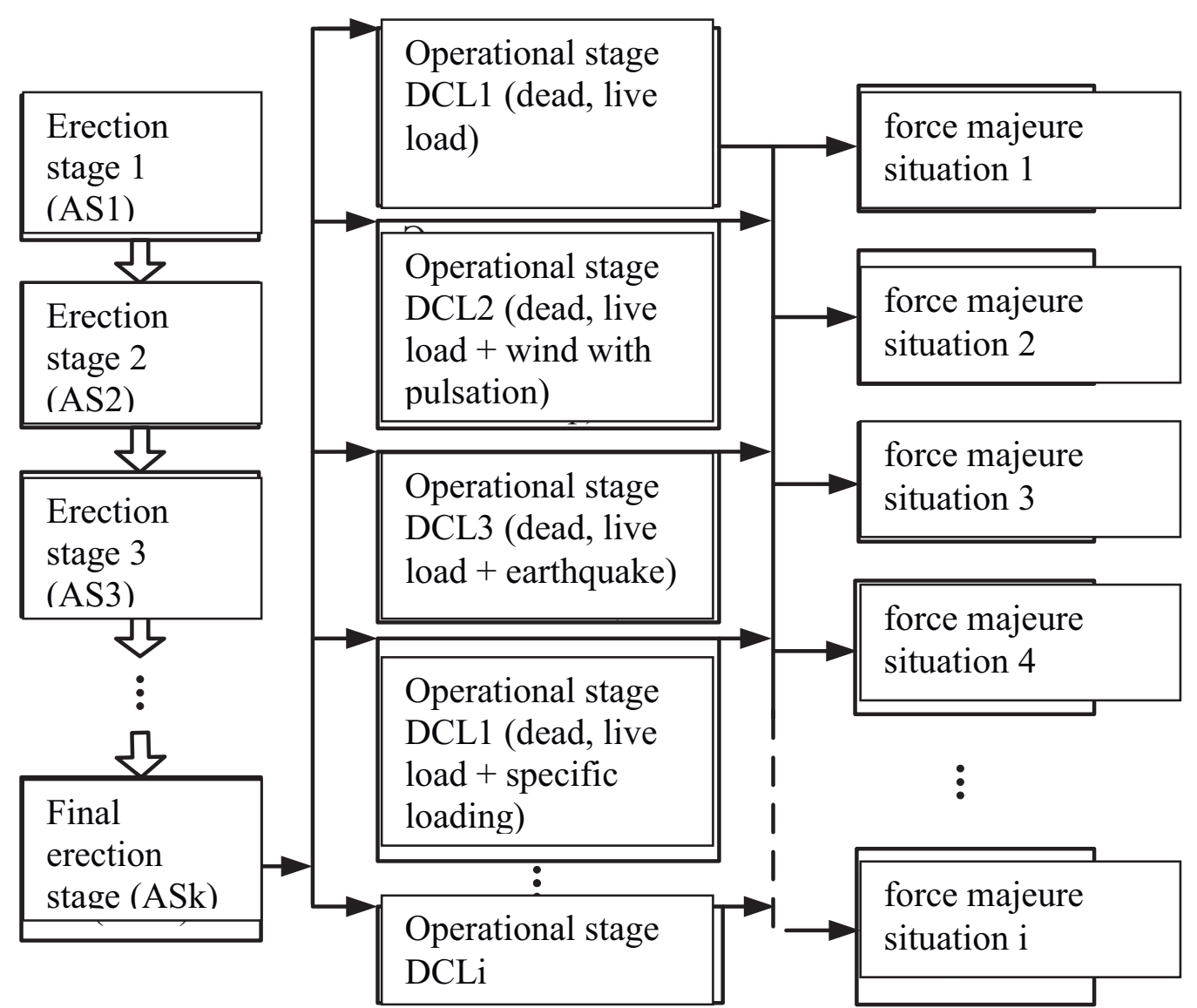

Figure 1. A possible design scheme of structures taking into account the stages of the life cycle of a building object.

Of course, such a simulation, even taking into account the increasing capabilities of modern computers, is cumbersome in addition to a large number of calculations of various structural schemes, each of them, as a rule, must be carried out taking into account geometric, physical, constructive, genetic nonlinearity. This is especially true for force majeure situations, when it is necessary to determine additional reserves of the structural bearing capacity in order to prevent progressive collapse with minimal additional material costs. In addition, the determination of the stress-strain state of costruction at operational stages should take into account temporary changes in the rheological properties of the material (shrinkage, creep, etc.), which also necessitates the calculation in a nonlinear formulation [4].

Carrying out such a calculation is nevertheless rather cumbersome and is currently used only when designing unique objects that have no analogues. As a rule, the vast majority of calculations are carried out according to the traditional scheme (Figure. 2).

The linear static analysis does not take into account a number of important factors, for example, the physical nonlinearity of reinforced concrete.

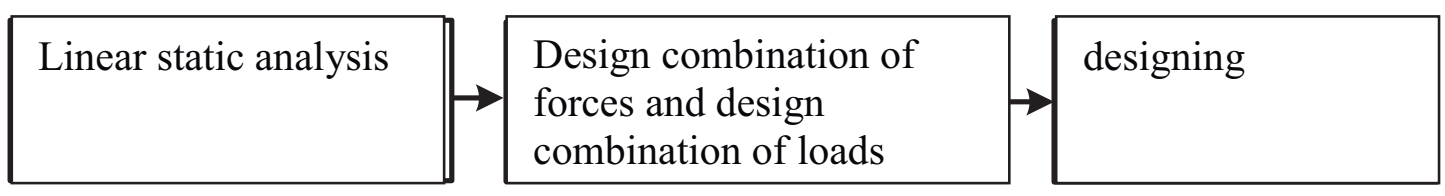

Figure 2. The traditional design scheme. 
This factor determines not only a significant increase in displacements (by a factor of 2-3 compared with the calculation in a linear formulation), but also a redistribution of forces, which adequately reflects the actual work of the structures.

The principle of "characteristic load" on the one hand implements the consideration of various factors that are not available when calculating in a linear formulation, on the other hand, it preserves the traditional calculation technology (Fig. 2).

\section{An example of the principle of "Characteristic loading" in the methodology "Engineering non-linearity"}

Creep, cracks, and other specific features of reinforced concrete cause a change in the stiffness characteristics of elements already in the early stages of loading, including the operational stage. This leads to a redistribution of forces, a significant increase in displacements compared with linear-elastic analysis. Regulatory documents orient the engineer to account for these factors. So Eurocode and the Russian Federation standards recommend to carry out the calculation taking into account physical non-linearity. The LIRA-SAPR software package provides an opportunity for an engineer to perform such calculations. However, the design calculation taking into account physical nonlinearity $[2,7,8]$ in the strict mathematical understanding of this process when used in mass engineering calculations has several disadvantages:

- such a calculation can only be performed for one load and cannot be used in DCF or DCL;

- such a calculation requires large resource costs since the step-type method makes it necessary to repeatedly solve systems of linearized equations;

- such a calculation requires specifying the reinforcement (diameters and location) in each section of the bar or plate element.

On the other hand, the standards of the Russian Federation SP 52-103-2007, to take these factors into account in engineering calculations, suggest simply introducing decreasing stiffness coefficients for bent elements 0.3 and compressed 0.6. Of course, such a crude assumption does not take into account that the decrease in stiffness depends on the magnitude and nature of the stress-strain state of the cross section. Nothing is said at all about reducing the stiffness of the stretched elements.

This approach roughly estimates the actual situation. This can be demonstrated by the example of an elementary beam clamped on the both edges (Figure 3).

a)

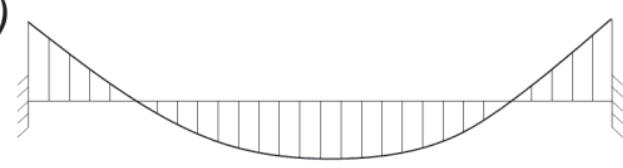

б)

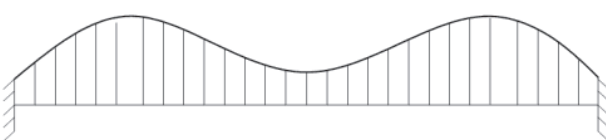

Figure 3. Stress-strain state of the clamped beam: a) diagram of moments, b) corresponding diagram of stiffness.

In real calculations, the situation is even more complicated: the columns often experience significant normal forces: the beams subjected to significant bending force; in plastic elements, as a rule, commensurate membrane and bending forces arise.

The Engineering Nonlinearity method (an iterative calculation method for determining load) is aimed at some elimination of this discrepancy (some ideas in this direction were proposed earlier [3]) and this method should be positioned as a method of improved differentiated accounting for the reduction of the stiffness characteristics of reinforced concrete elements.

\section{The method conception}

The Engineering Nonlinearity Method consists in the following:

1. A "characteristic load" is set, which, according to the engineer, mainly determines 
the stress-strain state of the structure (crack development, plastic deformation of concrete and reinforcement) throughout the life cycle of the structure. "Characteristic load" can be compiled on the basis of a set of loads (dead weight, payloads, etc.), which are set by the engineer for the subsequent traditional calculation or appointed by the engineer on the basis of other assumptions.

2. The calculation is made for "characteristic load" in a physically non-linear formulation with the simultaneous selection of reinforcement. The calculation is performed by the iterative method and the selection of reinforcement is performed.

3. As a result of an iterative calculation based on the stress-strain state of each section of the rod and the FE of the plate structure, the stiffness characteristics are determined.

4. A traditional structural analysis is performed. The elements of structure have stiffness characteristics determined as a result of an iterative calculation. The traditional calculation involves the calculation in a linear-elastic setting for the entire set of loads (dead weight, live load, earthquake, etc.), compiling the DCF or DCL, selecting or checking the cross-sections of the rods of reinforced concrete and steel elements, designing.

The most responsible and difficult in the formulation and implementation is the stage of determining the stiffness characteristics of the cross sections of the rod and plate element [9, $11]$.

Determination of the stiffness characteristics of the cross section of the rod

Figure 4 shows an arbitrary section of the rod, on which two moments $\mathrm{Mx}$ and $\mathrm{My}$ and the normal force $\mathrm{N}$ act. The moments act relative to the principal axes of the section $\mathrm{x}$ and $\mathrm{y}$. Normal force is applied at point $\mathrm{C}$ - the intersection of the geometrical axis of the rod with the section plane. Required: to determine the stiffness characteristics of the section corresponding to the secant modulus of deformation of concrete and reinforcement.
Figure 4 shows the sigma - eps dependence for concrete and Figure 5 shows the same dependence for reinforcement.

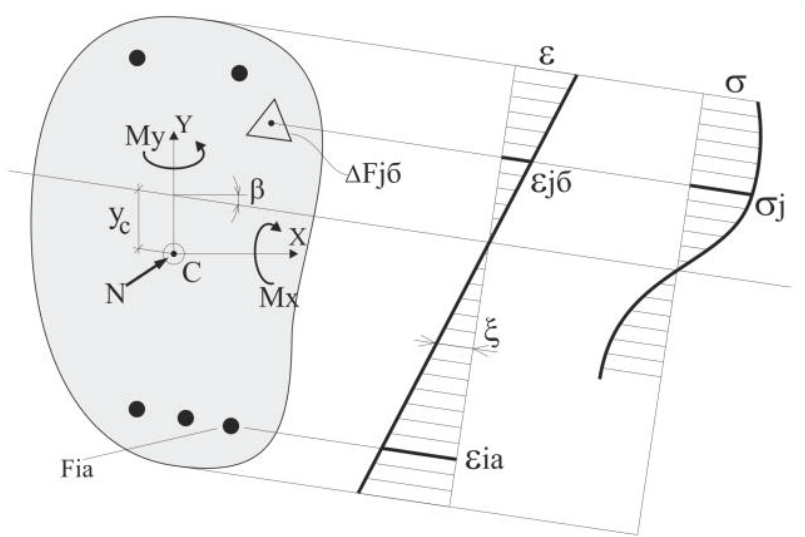

Figure 4. Stress-strain state of rod cross section
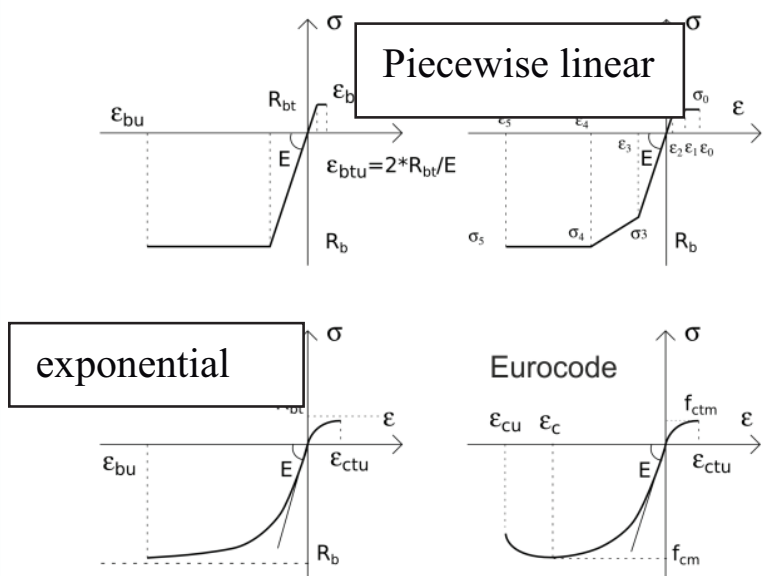

Figure 5. The stress-strain dependence for concrete

In order to determine the cross section stressstrain state, it is necessary to find the position of the neutral axis, which is characterized by two values of $Y c, \beta$ and the curvature of the section $\xi$ (Figure 4):

Yc is the offset of the neutral axis;

$\beta$ is the angle of rotation of the neutral axis;

$\xi$ is the curvature of the section.

The solution to the problem is performed by a numerical method. As a result of the iterative process, three unknowns Yc, $\beta, \xi$ are determined, which are found from three equilibrium equations: 
$\sum \mathrm{z}=0, \sum \mathrm{Mx}=0, \sum \mathrm{My}=0$.

$\sum z=\sum_{j=1}^{n} \Delta F_{j \sigma} \cdot \sigma_{j \sigma}\left(y_{c}, \beta, \xi\right)+$

$+\sum_{i=1}^{m} f_{i a} \sigma_{i a}\left(y_{c}, \beta, \xi\right)+N=0$

$\sum M_{x}=\sum_{j=1}^{n} \Delta F_{j \sigma} \cdot \sigma_{j \sigma}\left(y_{c}, \beta, \xi\right) y_{j}\left(y_{c}, \beta, \xi\right)+$

$+\sum_{i=1}^{m} f_{i a} \sigma_{i a}\left(y_{c}, \beta, \xi\right) y_{i a}\left(y_{c}, \beta, \xi\right)+M_{x}+N e_{x}=0$

$\sum M_{y}=\sum_{j=1}^{n} \Delta F_{j \sigma} \cdot \sigma_{j \sigma}\left(y_{c}, \beta, \xi\right) \cdot x_{j}\left(y_{c}, \beta, \xi\right)+$

$+\sum_{i=1}^{m} f_{i a} \sigma_{i a}\left(y_{c}, \beta, \xi\right) \cdot x_{i a}\left(y_{c}, \beta, \xi\right)+M_{y}+N e_{y}=0$

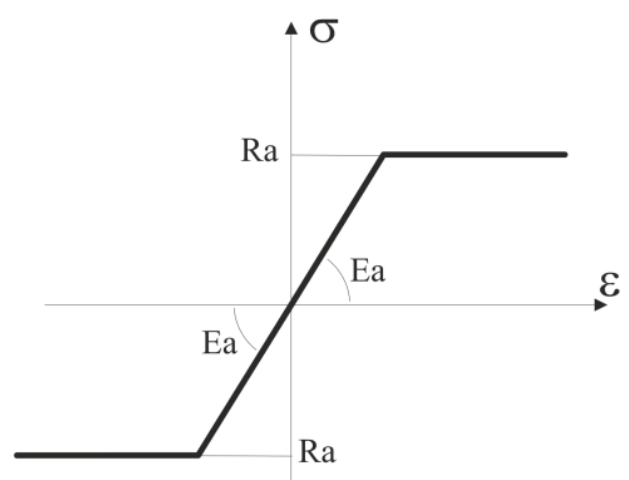

Figure 6. The stress-strain dependence for reinforcement

The stiffness characteristics of $\mathrm{E}_{\mathrm{ob}} \mathrm{F}, \mathrm{E}_{\mathrm{ob}} \mathrm{I}_{\mathrm{x}}, \mathrm{E}_{\mathrm{ob}} \mathrm{I}_{\mathrm{y}}$ are determined based on the $\sigma-\varepsilon$ dependences for concrete and reinforcement (Fig. 5, 6). For concrete, the definition includes only the compressed part of concrete with cross-sectional secant deformation models. For each reinforcing bar, the corresponding deformation modulus is also used.

$$
\begin{aligned}
& E_{o \sigma} F=\sum_{j=1}^{n} E_{\text {секj } \sigma} \Delta F_{j \sigma}+\sum_{i=1}^{m} E_{\text {секіa }} f_{\text {ia }} \\
& E_{\text {об }} I_{x}=\sum_{j=1}^{n} E_{\text {секј } \sigma} \Delta F_{j \sigma} y_{j \sigma}^{2}+\sum_{i=1}^{m} E_{\text {секіа }} f_{\text {ia }} y_{\text {ia }}^{2} \\
& E_{o \sigma} I_{y}=\sum_{j=1}^{n} E_{\text {ceкj } \sigma} \Delta F_{j \sigma} x_{j \sigma}^{2}+\sum_{i=1}^{m} E_{\text {ceкia }} f_{i a} x_{i a}^{2}
\end{aligned}
$$

Here $\Delta F_{j \sigma}, f_{i a}$ are elementary sections into which the concrete section and the area of individual reinforcement bars are divided; $\mathrm{n}$ is the number of concrete sections; $\mathrm{m}$ is the number of reinforcing bars; $E_{\text {секј }}, E_{\text {секіа }}-$ secant deformation modules of concrete and reinforcement, which are determined on the basis of dependencies $\sigma-\varepsilon$ (Figures 4,5); $\mathrm{x}_{\mathrm{j} \sigma}, \mathrm{y}_{\mathrm{j} \sigma}$, $\mathrm{x}_{\mathrm{ia}}, \mathrm{y}_{\mathrm{ia}}-$ the distance of the center of gravity of the $j$-th concrete section and the i-th section of the reinforcing bar to the main axes, the position of which $(\mathrm{Yc}, \beta)$ is determined as a result of iterative calculation.

For concrete, the definition of stiffness includes only the compressed part of concrete with a cross-sectional secant deformation modulus. For each reinforcing bar, the corresponding secant deformation modulus is also used.

The stiffness matrix of a rod having variablelength secant stiffness characteristics (Fig. 3) is also constructed numerically (each rod is considered as a kind of super element).

\section{Application examples}

Below are the results of calculating the frame based on engineering non-linearity 1 (Figure 7). The load $\mathrm{q}=15 \mathrm{t} / 1 \mathrm{~m}$ was adopted as the determining load. in fig. Figure 8 shows the corresponding stiffnesses for the crossbar b - c and the columns $a-b$. Analyzing the diagrams of stiffness characteristics, we can conclude that the recommended decrease in stiffness characteristics for columns by a decreasing factor of 0.6 (in this case, the diagram for columns would look constant and equal to $0.6 \times 2500=1500 \mathrm{tm} 2$ ) and for crossbars 0.3 (in this If the plot would look constant and equal to $0.3 \times 5900=1770 \mathrm{tm} 2$ ) it looks like a rather rough approximation.

Table 1 shows the results of linear-elastic calculation of the frame for the load $q=20 \mathrm{t} /$ 1.m. taking into account the differentiated distribution of stiffnesses for all elements obtained on the basis of the Engineering Nonlinearity 1 mode. 


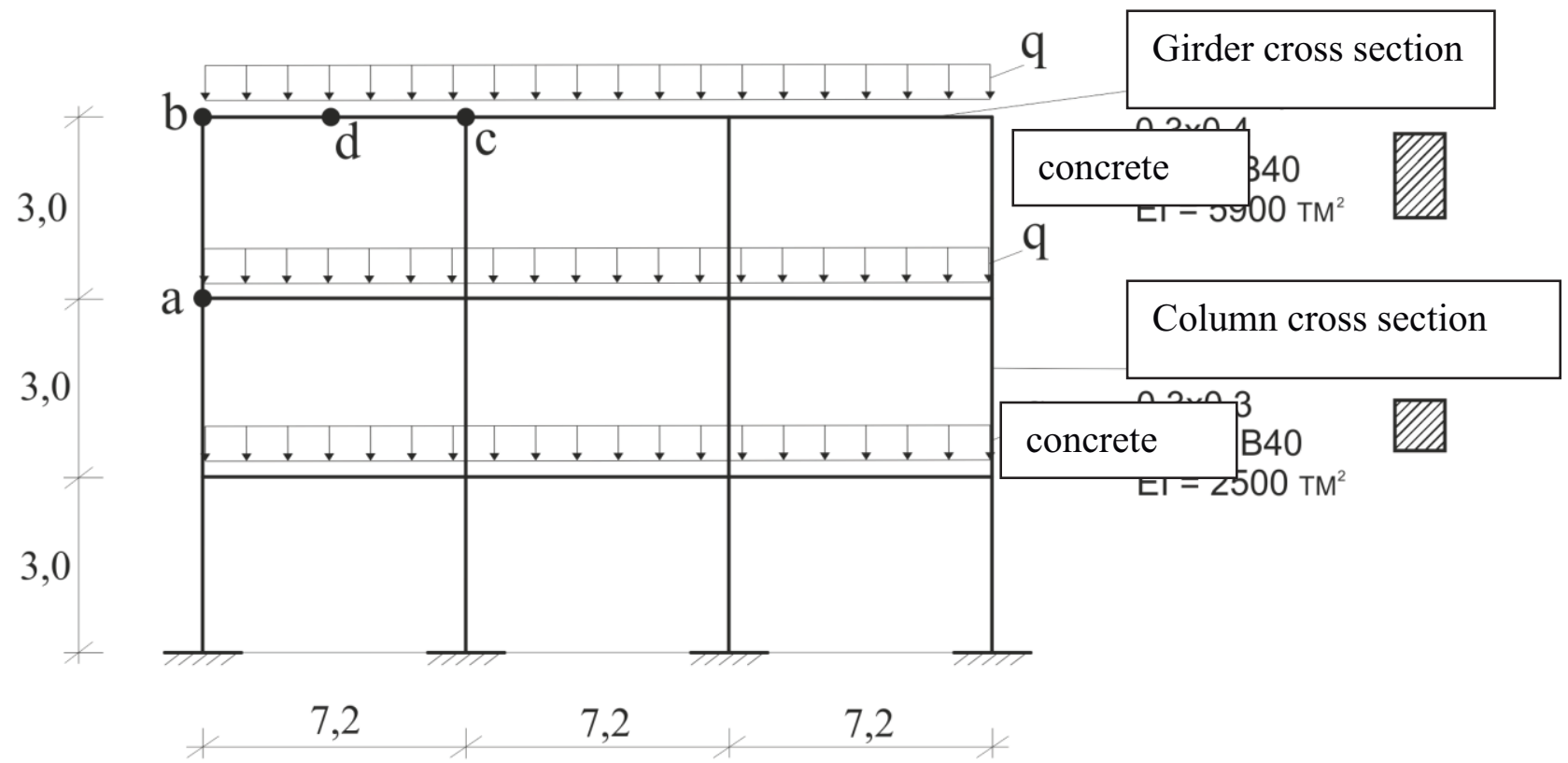

Figure 7. The design scheme of the investigated structure.

a)

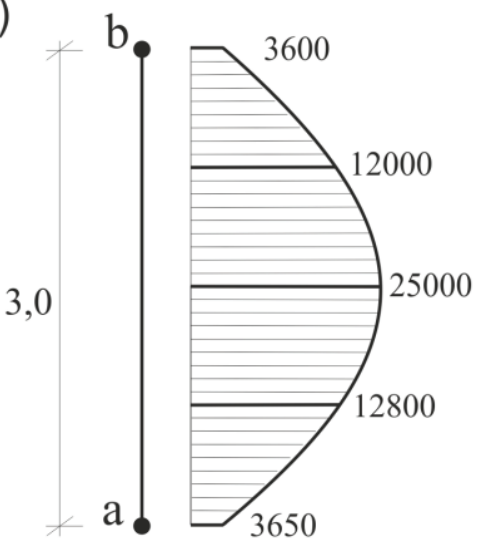

б)

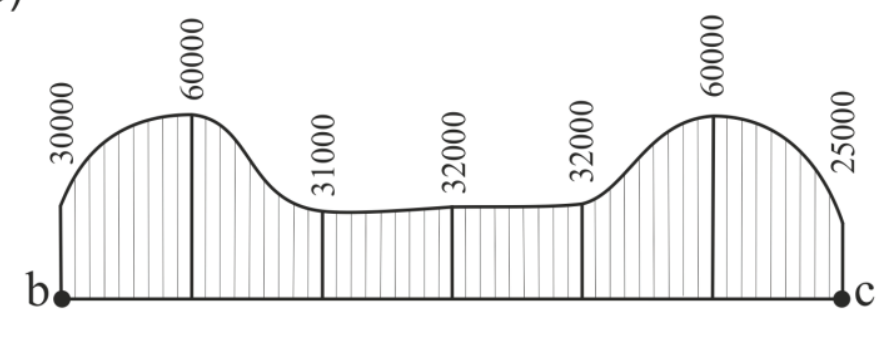

Figure 8. Plots of stiffness EI tm2 obtained on the basis of calculation by the method

"Engineering nonlinearity": a) for the column, b) for the crossbar.

Table 1. Linear-elastic analysis results for the frame.

\begin{tabular}{|c|c|c|c|c|c|}
\hline Value & & $\overline{\text { Static analysis }}$ & & Dynami & analysis \\
\hline $\begin{array}{l}\text { Type } \\
\text { of analysis }\end{array}$ & $\begin{array}{l}\text { The moment } \\
\text { in the } \\
\text { crossbar "b-c" } \\
\text { in the node } \\
\text { "b" in the tm }\end{array}$ & $\begin{array}{l}\text { The moment } \\
\text { in the } \\
\text { crossbar "b- } \\
c \text { " in the node } \\
\text { "d" in the tm }\end{array}$ & $\begin{array}{l}\text { Displacement } \\
\text { of the node } \\
\text { ' } \mathrm{d} \text { ', } \mathrm{B} \mathrm{mm}\end{array}$ & $\begin{array}{c}\text { Frequency } \\
\omega \\
\mathrm{Hz}\end{array}$ & $\begin{array}{l}\text { Period } \\
\text { T } \\
\text { sec. }\end{array}$ \\
\hline $\begin{array}{l}\text { Linear elastic analysis with } \\
\text { initial stiffness }\end{array}$ & -25.3 & 28.3 & -21.65 & 0.187 & 5.51 \\
\hline $\begin{array}{l}\text { Linear elastic analysis with } \\
\text { stiffness by "Engineering } \\
\text { Nonlinearity 1" }\end{array}$ & -28.6 & 25.5 & -32.84 & 0.162 & 6.32 \\
\hline $\begin{array}{l}\text { Linear elastic analysis with } \\
\text { stiffness by SP 52-103-2007 }\end{array}$ & -31 & 25.7 & -58.86 & 0.144 & 6.95 \\
\hline
\end{tabular}


Analyzing the calculation results given in table.

1, we can draw the following conclusions:

- $\quad$ some redistribution of efforts was obtained - in a less loaded cross-section "b" of the girder, the moment increased, in a more loaded cross-section "d" of the crossbar the moment decreased;

- the movement of the node " $d$ " increased by more than 2 times;
- the frequency of natural vibrations (first form) decreased, and the period increased. In LIRA-SAPR, a second version of engineering non-linearity was also developed, (Engineering non-linearity 2 is a step-by-step calculation method for determining load), which has its own characteristics (Table 2):

Table 2. Comparison of techniques Engineering nonlinearity 1 and 2.

\begin{tabular}{|l|l|l|}
\hline Concepts & Engineering Nonlinearity 1 & Engineering Nonlinearity 2 \\
\hline Characteristic load & can include arbitrary loads & $\begin{array}{l}\text { real permanent loads are } \\
\text { included }\end{array}$ \\
\hline $\begin{array}{l}\text { Calculation for } \\
\text { characteristic load }\end{array}$ & iterative & Step-type \\
\hline Reinforcement set up & $\begin{array}{l}\text { reinforcement is selected during the } \\
\text { iterative calculation }\end{array}$ & Reinforcement is accepted \\
\hline $\begin{array}{l}\text { Calculation by traditional } \\
\text { scheme }\end{array}$ & $\begin{array}{l}\text { the calculation is performed for all } \\
\text { loads based on secant deformation } \\
\text { moduli }\end{array}$ & $\begin{array}{l}\text { calculation for temporary loads } \\
\text { is performed on the basis of } \\
\text { the tangent deformation } \\
\text { modulus corresponding to the } \\
\text { last step of the step calculation }\end{array}$ \\
\hline $\begin{array}{l}\text { Account of physical non } \\
\text { linearity in assemblage }\end{array}$ & is absent & available \\
\hline $\begin{array}{l}\text { Account of nonlinear } \\
\text { behavior of nodes }\end{array}$ & is absent & available \\
\hline
\end{tabular}

An example of the application of the principle of "Characteristic load" when assigning subgrade reaction moduli

The values of the subgrade reaction moduli depend on the depth of the compressible stratum, which in turn depends on the load. Thus, this leads to a nonlinear formulation of the problem.

An example of the principle of "Characteristic loading" allows you to carry out the calculation according to the following scheme:

1. First, we assign a uniform stress under the sole of the footing by dividing the mass of the building by the area of the footing (step 1, Fig. 9). We get variable subgrade reaction moduli according to the footing area from uniform stress under the sole. We apply soil rebuff from the selected characteristic load (step 2-4, Figure 9).
2. We determine the subgrade reaction moduli for each finite element of the foundation structure from uneven stress under the bottom of the foundation (step 5, Figure 9).

3. Calculation according to the traditional scheme for all loads, taking into account those found in section 2 subgrade reaction moduli.

When modeling pile foundations in LIRASAPR software, it is possible to specify the loads on the pile heads to recalculate the stiffnesses (the stiffnesses change taking into account the mutual influence of sediments in the pile group, since the loads on the heads of the neighboring piles have changed). Starting with the LIRA-SAPR 2019 version, a tool has been implemented to automate iterative calculations (without user intervention) (Figure 10). 


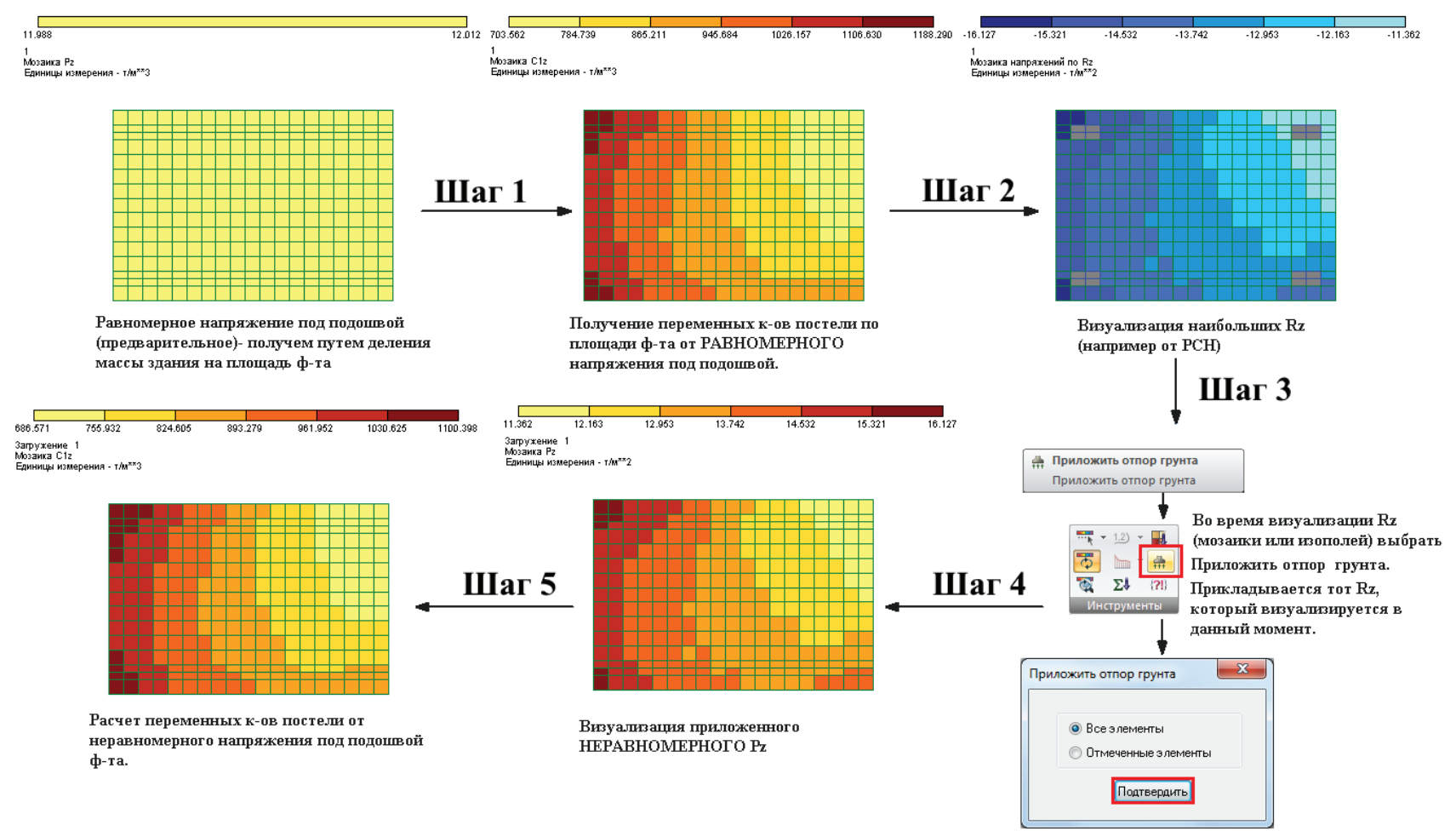

Figure 9. Algorithm for determining the magnitude of bed coefficients for each finite element of the foundation structure.

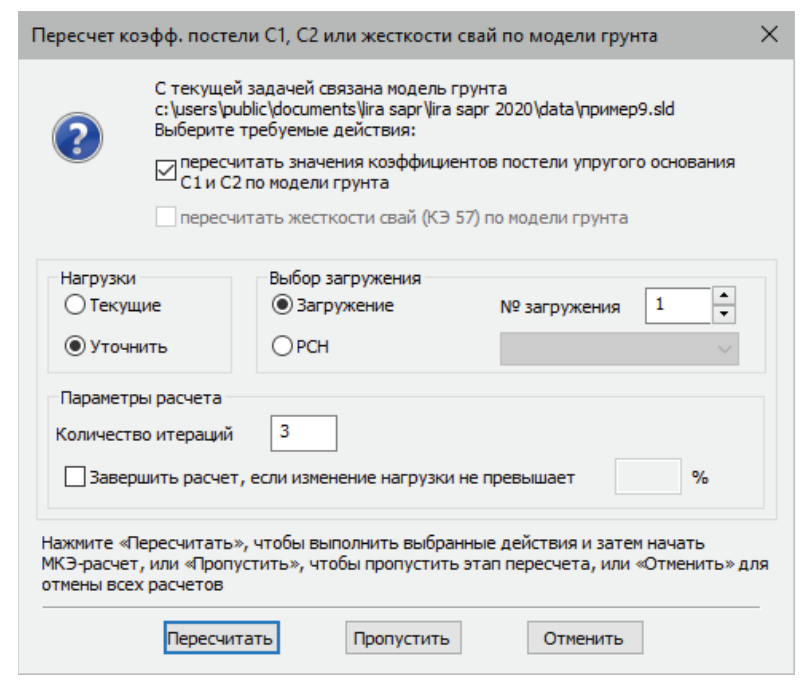

Figure 10. Dialog window calculating subgrade reaction modulus C1, C2 or stiffness of piles according to soil model.

Application of the principle of "Characteristic load" in the determination of the sizes of shelves for beam grillage

Reinforcement of slabs with beams is often found in modern housing construction. The arrangement of beams, as a rule, is irregular, there is no clearly defined system of main and secondary beams, the beams can have a small height, and here loads are often transferred to the supports due to the operation of both the slab itself and the beams.

In this case, the experience of calculating and designing ribbed floors (these examples are available in each textbook on reinforced concrete structures, where it is recommended to collect the load from the slab on the secondary beams, considering the support of the slab on them rigid, then calculate the secondary beams, considering their bearing on the main beams rigid and etc.) is unsuitable and may have only antique value.

On the other hand, from the point of view of the finite element method, it would seem that there should be no problems: a finite element grid of the slab is introduced with base points on the lines of the beams, a load is applied on the top of the slab, etc. But there are many problems associated with linking of elements of different dimensions in a finite element model. The main 
problem here is how to assign the rigidity of the beam.

If we introduce rods with the hc $\mathrm{x}$ bc crosssection into the finite element model of the slab, the grid nodes of which lie on the middle surface, then the system with the mutual arrangement of the slab and the beam shown in Fig. 11b. Of course, such a model does not stand up to criticism. You can enter a T-section of the beam. The mutual arrangement of the slab and the beam in this case is shown in Fig. 11, c. However, the question arises of how to assign the width of the shelf. Different textbooks give different recommendations - from 6 to 15 plate thicknesses. In addition, according to this scheme, the work of the plate is taken into account twice. However, this is quite acceptable, since the finite elements of the plate simulate a bending force group, and part of the plate as part of the beam shelf models the membrane force group, which causes small

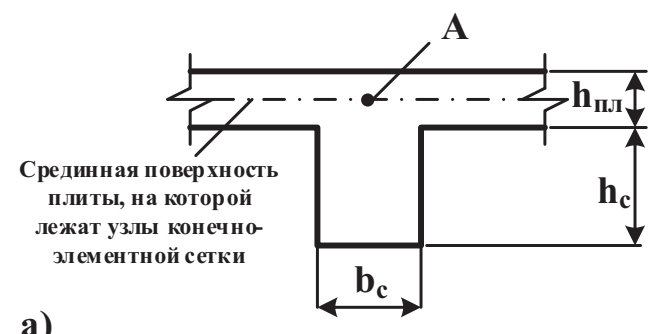

a)

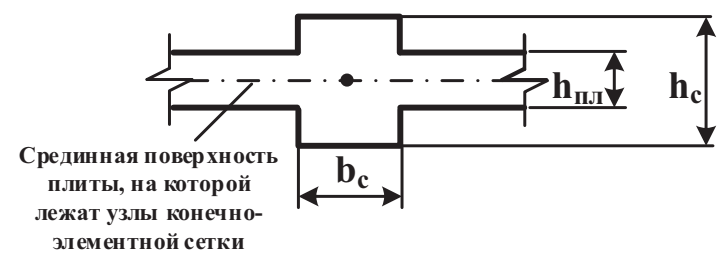

б)

\section{Figure 11. Modeling slab reinforced beams.}

Although the latter model most fully reflects the actual work of the structure, and removes the question of the appointment of the width of the shelves in the T-beam, however, difficulties arise at the last stages of beam design. Of course, you can simply calculate the cross section of the rod hc $\mathrm{x}$ bc on the basis of the efforts Mc, and Nc. However, as a rule, the value of Nc is large, and the cross section will stresses in the plate compared to stresses from the bending group. The model proposed in [10] is quite adequate, where the interaction of the slab and the beam is shown in Fig. 11, d.

In this case, the rods with hc $\mathrm{x}$ bc section are suspended using absolutely rigid inserts to the nodes of the finite element model of the plate lying in its middle surface. Here (in contrast to the models in Fig. 11b and Fig. 11c, where in the finite elements of the plate and rods only a bending group of forces arises, and each node of the finite element circuit has three nodal unknowns - vertical movement and two rotation angles), each node of finite element model has five nodal unknowns - three linear displacements and two rotation angles, and the finite elements of the plate subjected a membrane force group as well as the bending group, and in the rod element, in addition to the bending moment (Ms) and the transverse force, a normal force $(\mathrm{Nc})$ also appears .

B)
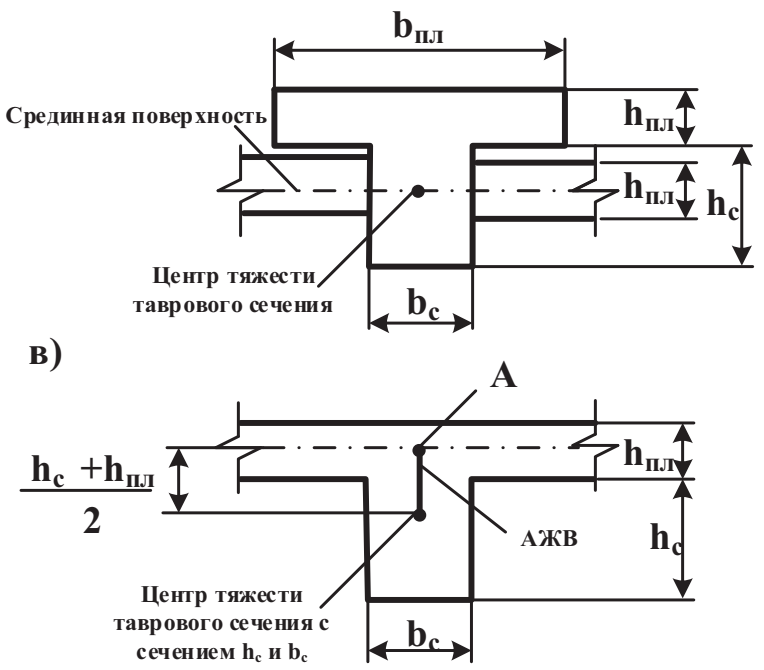

г)

be designed as an eccentrically stretched element, and the selected reinforcement in it will be distributed around the entire perimeter, while according to the rules for constructing beam grillages, the reinforcement should be located at the lower and upper faces. Thus, for designing, it is desirable to consider the Tsection of the beam subject to bending, however, it is unclear what bending moment 
acts on the beam and what section of the beam must be calculated. In this case, the following engineering approach can be considered, based on the hypothesis that the resultant membrane forces of the plate, balancing the normal force in the suspended rod $(\mathrm{Nc})$ applied in the center of the plate (point A of Fig . 12a). Then we can assume that the bending moment acting on the beam of the T-section is equal to $\mathrm{Mb}=\mathrm{Ms}+$ $\mathrm{Nx} 0.5$ (hs $+\mathrm{hn}$ ). It remains only to determine the width of the shelf of the T-beam. Here, with some exaggeration, the above hypothesis can be used: if the center of gravity of the membrane forces is applied in the center of the plate part (point A), then the shelf should be uniformly compressed. Since the reinforcement will be calculated under assumptions about the ultimate state of the section, the stresses in the shelf will be $\mathrm{Rb}$. Therefore, the width of the shelf $\mathrm{bn}=\mathrm{Nc}$ $/(\mathrm{hn} \times \mathrm{Rb})$.

The shear force in the beam is defined as the first derivative (finite-difference approach is used in numerical calculations) of the moments $\mathrm{Mb}(\mathrm{x})$. Since the diagrams $\mathrm{Mc}$ and $\mathrm{Nc}$ in the rod have a stepped form, ie, in each section there are two values of the moment and normal force, they should either be averaged or their values should be taken in the middle of the segments. Of course, the assumptions that the stresses in the shelf for determining $\mathrm{Mb}$ are assumed to be constant, and when determining $\mathrm{bn}$, are equal to $\mathrm{Rb}$, in some cases may not be successful enough, therefore, a slightly different approach based on the hypothesis of flat sections is given below (Fig. 12b). The deformation of the cross section is determined on the basis of the diagram of stresses in the cross section of the rod:

$$
\begin{gathered}
\sigma_{\max }=+N_{c} / F_{c}+M_{c} / W_{c} ; \\
\sigma_{\min }=+N_{c} / F_{c}-M_{c} / W_{c} ; \\
F_{c}=h_{c} \times b_{c} ; \\
W_{c}=b_{c} \cdot h_{c}^{2} / 6 .
\end{gathered}
$$

Further, the slope of the cross-section is extended into the plate region and determined from geometric ratios $\sigma_{n}, y, z, R_{\text {сж⿱ }}=R_{\text {pacm }}$.

After that, the definition of $\mathrm{Mb}$ and bn seems to be a matter of technique:

$$
\begin{gathered}
M_{\sigma}=R_{\text {pacm }} \times z ; \\
b_{h}=R_{\text {см }} /\left(0.5 \sigma_{n} \times y\right) .
\end{gathered}
$$

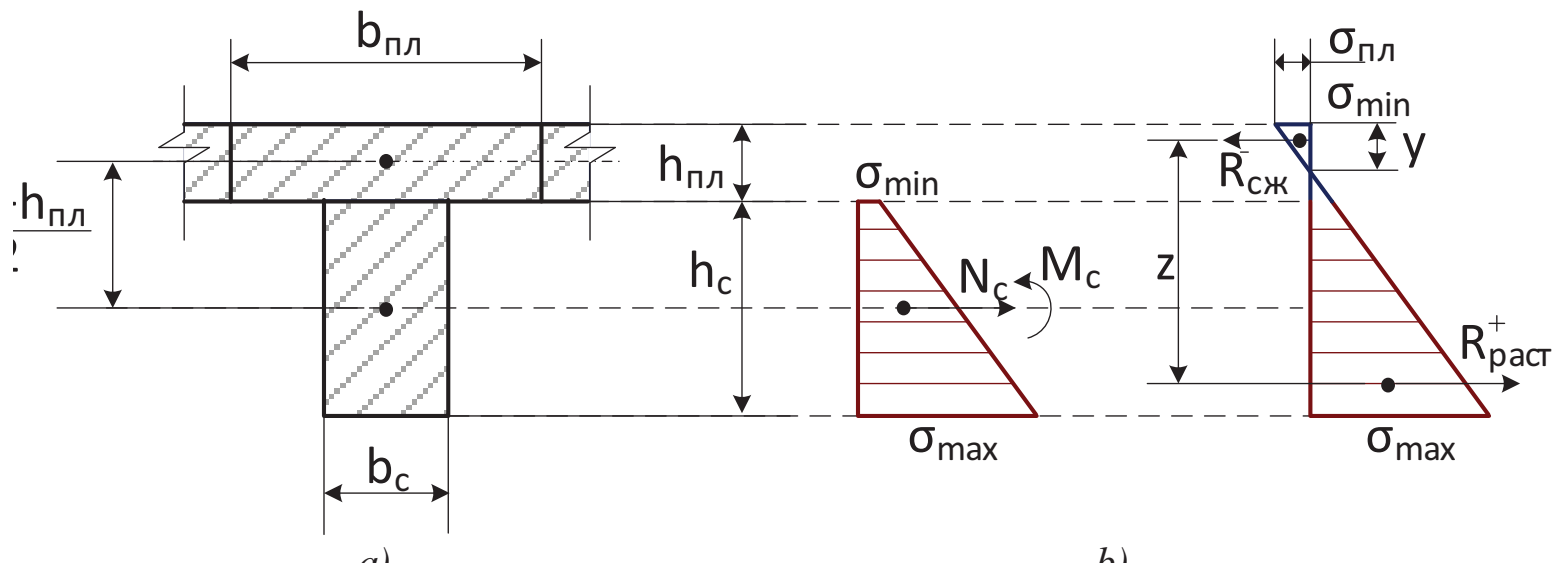

a)

Figure 12. Determining the width of the shelf of the T-beam.

In this case, the principle of "characteristic load" allows the calculation according to the following scheme.

1. Set up of the characteristic load.
2. Determination of the width of the shelf according to the above method for each section of the beam grillage. 
3. Calculation of the beam grillage for all loads with the dimensions of shelves designated according to section 2 .

\section{CONCLUSIONS}

Examples of the application of the principle of "characteristic load" are considered, apparently it does not exhaust all areas of its application. Engineering practice will prompt these areas, which will be implemented in the LIRA-SAPR Software.

\section{REFERENCES}

1. Barabash M.S. Vlijanie processa vozvedenija na prostranstvennuju rabotu nesushhih sistem zdanij [Influence of the erection process on the spatial work of load-bearing systems of buildings]. // Construction, materials science, mechanical engineering. Scientific Proceedings. Dnepropetrovsk, PGASA, 2012, No. 65, pp. 29-34 (in Russian).

2. Barabash M.S. Komp'juternoe modelirovanie processov zhiznennogo cikla objektov stroitel'stva [Computer simulation of the life cycle of construction projects]. Kiev, Stal, 2014, 301 pages (in Russian).

3. Bondarenko V.M. Inzhenernye metody nelinejnoj teorii zhelezobetona [Engineering methods of the nonlinear theory of reinforced concrete]. Moscow, Stroyizdat, 1982, 287 pages (in Russian).

4. Gorodetsky A.S., Evzerov I.D. Komp'juternye modeli konstrukcij [Computer models of structures]. The Second Edition. Kiev, FACT, 2007, 394 pages (in Russian).

5. Gorodetsky A.S., Barabash M.S. Komp'juternoe modelirovanie processa vozvedenija stroitel'nyh konstrukcij [Computer simulation of the process of erection of building structures]. //
Structural mechanics and calculation of structures, 2014, Issue 5(256), pp. 28-33 (in Russian).

6. Gorodetsky A.S., Barabash M.S., Sidorov V.N. Komp'juternoe modelirovanie $\mathrm{V}$ zadachah stroitel'noj mehaniki [Computer modeling in the problems of structural mechanics]. Moscow, ASV Publishing House, 2016, 338 pages (in Russian).

7. Gorodetsky A.S., Zdorenko V.S. K raschetu fizicheski nelinejnyh ploskih ramnyh system [To the calculation of physically nonlinear planar frame systems] Structural mechanics and calculation of structures, 1969, No. 4, pp. 61-68 (in Russian).

8. Gorodetsky A.S. Komp'juternoe modelirovanie processa nagruzhenija zhelezobetonnyh konstrukcij [Computer simulation of the process of loading reinforced concrete structures]. // Collection of scientific works of the Lugansk National University, a series of "Technical Sciences", No. N49 / 52, Lugansk, "LNAU" Publishing House, 2004, pp. 3-10 (in Russian).

9. Gorodetsky A.S., Barabash M.S. Uchet nelinejnoj raboty zhelezobetonnyh konstrukcij $\mathrm{V}$ prakticheskih raschetah [Accounting for the nonlinear work of reinforced concrete structures in practical calculations]. // Construction, materials science, mechanical engineering. Scientific Proceedings. Dnepropetrovsk, PGASA, 2014, Issue 77, pp. 54-59 (in Russian).

10. Gorodetsky A.S., Evzerov I.D., StreletsStreletsky E.B. and others. Metod konechnyh jelementov: teorija i chislennaja realizacija [The finite element method: theory and numerical implementation]. Kiev, FACT, 1997, 138 pages (LIRAWindows software package) (in Russian).

11. Pikul A.V., Gorodetsky A.S. Opredelenie zhestkostnyh harakteristik sechenija zhelezobetonnogo sterzhnja s uchetom nelinejnyh svojstv materiala 
[Determination of the stiffness characteristics of the cross section of a reinforced concrete rod taking into account the nonlinear properties of the material]. // Actual problems of computer modeling of structures and structures: abstracts of the IV International Symposium. Chelyabinsk, Publishing Center of SUSU, 2012, p. 228 (in Russian).

\section{СПИСОК ЛИТЕРАТУРЫ}

1. Барабаш М.С. Влияние процесса возведения на пространственную работу несущих систем зданий. // Строительство, материаловедение, машиностроение // Сб. научных трудов. - Днепропетровск, ПГАСА, 2012, №65, c. 29-34.

2. Барабаш М.C.

Компьютерное моделирование процессов жизненного цикла объектов строительства. - Киев: Сталь, 2014. - 301 с.

3. Бондаренко В.М. Инженерные методы нелинейной теории железобетона. - М.: Стройиздат, 1982. - 287 с.

4. Городецкий А.С., Евзеров И.Д. Компьютерные модели конструкций. Киев: ФАКТ, 2007. - 394 с.

5. Городецкий А. С., Барабаш М. С. Компьютерное моделирование процесса возведения строительных конструкций. // Строительная механика и расчет сооружений, 2014, Выпуск 5(256), с. 2833.

6. Городецкий А.С., Барабаш М.С., Сидоров В.Н. Компьютерное моделирование в задачах строительной механики. - М.: АСВ, 2016. - 338 с.

7. Городецкий А. С., Здоренко В.С. К расчету физически нелинейных плоских рамных систем. // Строительная механика и расчет сооружений, 1969, №4, c. 61-68.

8. Городецкий А. С. Компьютерное моделирование процесса нагружения железобетонных конструкций. // Сборник научных трудов Луганского национального университета, серия «Технические науки», №49/52. Луганск: Из-во «ЛНАУ», 2004, с. 3-10.

9. Городецкий А.С., Барабаш М.С. Учет нелинейной работы железобетонных конструкций в практических расчетах. // Строительство, материаловедение, машиностроение. Сборник научных трудов. - Днепропетровск: ПГАСА, 2014, Выпуск 77, с. 54-59.

10. Городецкий А.С., Евзеров И.Д., Стрелец-Стрелецкий Е.Б. и др. Метод конечных элементов: теория и численная реализация. - Киев: ФАКТ, 1997. - 138 с. (программный комплекс ЛИРА-Windows).

11. Пикуль A.B., Городецкий А.С.. Определение жесткостных характеристик сечения железобетонного стержня с учетом нелинейных свойств материала. // Актуальные проблемы компьютерного моделирования конструкций и сооружений: тезисы докладов IV Международного симпозиума. Издательский центр ЮУрГУ, 2012, c. 228.

Alexander S. Gorodetsky, Foreign Member of the Russian Academy of Architecture and Construction Sciences (RAACS), Professor, DSc; Deputy Director for Science of "LIRA SAPR" Ltd; 7a, Kiyanovsky side street (pereulok), Kiev, 04053, Ukraine,

phone: +38 (050) 3519661 ;

E-mail: info@liraland.com.ua, http: www.liraland.ru.

Maria S. Barabash, Academician of the Academy of Construction of Ukraine, DSc (Eng.); Director of "LIRA SAPR" Ltd; Associate Professor, Professor of Department of Computer Technology Building, Educational and Scientific Institute of Airports, National Aviation University; 1, Kosmonavta Komarova, 03058, Kiev, Ukraine; phone: +38 (095) 286-39-90;

E-mail: bmari@ukr.net,http:www.liraland.ru; https://orcid.org/0000-0003-2157-521X;

Researcher ID: R-9181-2016. 
Maryna A. Romashkina, PhD, Support Engineer of "LIRA SAPR" Ltd, 7a, Kiyanovsky side street (pereulok), Kiev, 04053, Ukraine; phone: +38 (095) 931-52-50;

E-mail: romashkina.liraland@gmail.com;

http: www.liraland.ru;

ORCID ID: 0000-0002-7158-4037.

Andrii V. Tomashevskyi, postgraduate student, Computer Technologies of Construction Department, National Aviation University; software engineer "LIRA SAPR" Ltd, 7a, Kiyanovsky side street (pereulok), Kiev, 04053, Ukraine; phone: +38 (096) 22538 42;

E-mail: tomashevsky.a.v@gmail.com;

ORCID ID: 0000-0001-5960-2100.

Городецкий Александр Сергеевич, иностранный член Российской академии архитектуры и строительных наук (РАACH), профессор, доктор технических наук; заместитель директора по научной работе, ООО «ЛИРА САПР»; 04053, Украина, г. Киев, Кияновский переулок 7-а; тел.: +38 (050) 35196 61;

E-mail: info@liraland.com.ua,http: www.liraland.ru.

Барабаш Мария Сергеевна, академик Академии строительства Украины, доктор технических наук; директор ООО «ЛИРА САПР», профессор кафедры компьютерных технологий строительства Учебнонаучного института Аэропортов, Национального авиационного университета; 03058, Украина, г. Киев, проспект Космонавта Комарова, д. 1;

тел: +38 (095) 286-39-90;

E-mail: bmari@ukr.net, http: www.liraland.ru

ORCID ID: 0000-0003-2157-521X;

Researcher ID: R-9181-2016.

Ромашкина Марина Андреевна, кандидат технических наук; инженер группы сопровождения, ООО «ЛИРА САПР»; 04053, Украина, г. Киев, Кияновский переулок 7-а, тел. +38 (095) 931-52-50;

E-mail: romashkina.liraland@gmail.com, http: www.liraland.ru,

ORCID ID: 0000-0002-7158-4037.

Томашевский Андрей Владимирович, аспирант кафедры компьютерных технологий строительства Национального авиационного университета; инженерпрограммист ООО «ЛИРА САПР»; 04053, Украина, г. Киев, пер. Кияновский, д.7-а; тел.: +38 (096) 22538 42;

E-mail: tomashevsky.a.v@gmail.com; ORCID ID: 0000-0001-5960-2100. 